\title{
Rehabilitation of Red Mud Tailings Produced at the Aughinish Alumina Refinery
}

\author{
R. Courtney Department of Life Sciences, University of Limerick, Ireland
}

\section{INTRODUCTION}

The Aughinish Alumina Limited (AAL) Bayer Plant in South West Ireland produces approximately 1.7 million tonnes of alumina per annum. During the Bayer Process, two distinct residue fractions are produced and separated before disposal. These residues are differentiated into a fine fraction 'red mud' and a coarse fraction of 'process sand'. The principal residue, red mud, is produced at a rate of approximately 1.05 million tonnes per annum and about 0.15 million tonnes of process sand is also produced. There are an estimated 84 global alumina producers generating an estimated $65+\mathrm{M}$ tonnes of processing residue per annum (Prasad et al., 1996).

\subsection{Bauxite residue production and disposal}

Generally, red mud slurries are alkaline ( $\mathrm{pH} 11-13$ ), contain 10-30\% solids, extremely fine-sized (>60\% less than 10 microns) and possess inherently poor settling properties (Prasad et al., 1996). The conventional landfill disposal approach or Closed Cycle Disposal (CCD) is the cheapest in capital and operating costs. In this method, washed red mud slurry containing $10-30 \%$ solids is pumped to an impoundment area. When the mud has settled the supernatant liquor is recycled back to the plant. Problems with handling and transporting such high volumes of material include a high pumping energy, rapid wear in pipeline and pumps, slow rate of sedimentation and consolidation of fine mud leading to reduced life of disposal areas and slow rehabilitation (Nguyen and Boger, 1987 and 1998).

The method employed at AAL is a modification to the CCD method, 'semi dry' or dry stacking of the mud. The mud fraction is dewatered by vacuum filtration to a solids concentration of $63 \mathrm{wt} \%$ before being slightly diluted and transported, by a $2 \mathrm{~km}$ pipeline, to the bauxite residue disposal area (BRDA) where it is discharged and spread and allowed to consolidate and dry in layers $(\leq 300 \mathrm{~mm})$. Typically, the red mud is allowed to dry for approximately 3 months before depositing the next layer. The deposited mud is retained by a series of $2 \mathrm{~m}$ high rockfill dykes underlain by separation/filter layer of process sand. By 2010 seven of these raises will give the stack a height of 26 metres from ground level.

The current area of the BRDA is approximately 104 ha with future planning to extend this by a further 80 ha to accommodate a plant alumina production rate of $1.95 \mathrm{mtpa}$ by 2010 . A vegetation system is seen as a desirable goal in landscaping the BRDA and stabilizing the residue against dust generation and water erosion. 


\subsubsection{Legislative implications in the environmental management and storage of bauxite residue}

The Irish Environmental Protection Agency (EPA) issued an Integrated Pollution Control (IPC) licence to AAL (2004) and this governs BRDA operations within the meaning of the Waste Management Act, 1996. In addition, certain EC directives are relevant in the environmental management of the BRDA.

Both red mud and process sand are classified as non-hazardous waste under the Hazardous Waste Directive (91/689/EC). The Waste Framework Directive (75/442/EC, amended 91/156/EC, 91/692/EC and 96/350/EC) is the main directive governing waste. In addition, the Landfill of Waste (99/31/EC) stipulates that "measures should be taken to minimise nuisances and hazards arising from the landfill through emissions of odours and dust" and that the site be "adequately monitored and managed to prevent or reduce potential adverse effects on the environment and risks to human health".

The Proposal for a Directive on The Management of Waste Resulting for Prospecting, Extracting, Treatment and Storage of Minerals states in Article 12 - Prevention of Water and Soil Pollution from Disposal Facilities that the operator take appropriate measures in order to "prevent surface water and/or ground water being contaminated by the waste" and "prevent leachate generation as far as technically achievable".

\subsection{BRDA management and revegetation studies at AAL}

Although plant establishment is seen as a desirable means to achieve landscaping and stabilizing of the residues it is not a straightforward process. Problems presented in trying to achieve direct vegetation establishment include $\mathrm{pH}$ values of up to 12 and high levels of exchangeable sodium (ESP) resulting from the presence of caustic remaining after use during the ore processing. The predominance of the fine fraction is a major constraint limiting red mud reclamation efforts (Wong and Ho, 1994). Inherently small particle size $\left(90 \% \leq 35\right.$ microns and $35 \% \leq 2$ microns) results with low permeability, $1 \times 10^{-8}$ to $1 \times 10^{-9} \mathrm{~m} / \mathrm{sec}$ (Anon et al., 1993). Without drainage and reduction in $\mathrm{pH}$, soluble levels of $\mathrm{Al}$ and $\mathrm{Fe}$ can be high and therefore pose a risk to plant growth and uptake. The coarse fraction of the residues can present fewer difficulties in establishing vegetation because of the higher hydraulic conductivity, which increases leaching and thereby reduces the salinity and alkalinity (Meecham and Bell, 1977). Gypsum is commonly used as a soil amendment to achieve reduction in pH and ESP in sodic soils and alkaline residues (Wong and Ho, 1994).

\section{METHODOLOGY}

As part of the BRDA rehabilitation programme, a field study was initiated at AAL in 1999 to determine if indigenous grassland species were capable of growing on amended red mud that had been deposited 3 yrs previously. A trial area was established on the southwestern perimeter of the BRDA. Red mud was amended with gypsum $(3 \% \mathrm{w} / \mathrm{w})$, process sand $(25 \% \mathrm{w} / \mathrm{w})$, and treated sewage sludge $(35 \mathrm{t} / \mathrm{ha})$ and sown with three grassland species (Trifolium prantense, Holcus lanatus and Lolium perenne). 
Residue samples were taken at trial initiation and after one years growth, herbage and soil samples were taken and analyzed. An ecological survey of the rehabilitated area was conducted and species diversity recorded in 2005.

\section{RESULTS AND DISCUSSION}

Unamended bauxite residues (mud fraction and sand fraction) exhibited high soluble sodium levels, and together with the low values for $\mathrm{Ca}$ and $\mathrm{Mg}$, resulted in ESP values of $>60 \%$ (Table 1). High soluble $\mathrm{Al}$ levels were also recorded for both residues, and soluble Fe was significantly higher in the red mud fraction than in the sand. High $\mathrm{pH}$ values were recorded for both fractions reflecting the 'freshness' of the residues. Characteristics exhibited by the residues indicate that plant establishment would not be successful on unamended residue. Principally, high ESP values would inhibit plant growth (Wong and Ho, 1994).

Table 1 Chemical characteristics of bauxite residues prior to amendment

\begin{tabular}{|l|l|l|l|l|l|l|l|}
\hline & $\mathbf{p H}$ & $\begin{array}{l}\mathbf{N a} \\
(\mathbf{m g} / \mathbf{k g})\end{array}$ & $\begin{array}{l}\mathbf{C a} \\
(\mathbf{m g} / \mathbf{k g})\end{array}$ & $\begin{array}{l}\mathbf{M g} \\
(\mathbf{m g} / \mathbf{k g})\end{array}$ & $\begin{array}{l}\mathbf{A l} \\
(\mathbf{m g} / \mathbf{k g})\end{array}$ & $\begin{array}{l}\mathbf{F e} \\
(\mathbf{m g} / \mathbf{k g})\end{array}$ & $\mathbf{E S P}$ \\
\hline Mud & 9.7 & 1120 & 3.8 & 1.4 & 30 & 52 & 62 \\
& $(0.03)$ & $(62.2)$ & $(0.14)$ & $(0.04)$ & $(0.8)$ & $(1.6)$ & $(1.9)$ \\
\hline Sand & 10.2 & 3600 & 2.6 & 0.8 & 22 & 1.6 & 86 \\
& $(0.03)$ & $(160)$ & $(0.14)$ & $(0.01)$ & $(1.1)$ & $(0.1)$ & $(2.6)$ \\
\hline
\end{tabular}

Values in parentheses are standard error of mean of 8 samples $(n=8)$.

Following a period of weathering, analysis of the amended residue yielded values for the critical parameters that indicated plant growth was possible (data not shown). Soil samples were again taken following oneyear's plant growth (Table 2).

Parameters that are inhibitory to plant establishment and growth on bauxite residue (notably, $\mathrm{pH}, \mathrm{Al}, \mathrm{Fe}$, and $\mathrm{Na}$ ) had all significantly decreased compared to those recorded at the time of trial implementation. Relationships between the parameters $\mathrm{pH}$ and Al solubility and ESP and Al solubility were found. Exchangeable $\mathrm{Ca}$ levels in the residue are higher than the $660 \mathrm{mg} / \mathrm{kg}$ cited as being satisfactory for the growth of corn (Chapman, 1966).

Magnesium availability in the residue may be affected, as exchangeable magnesium in the range of 25-60 $\mathrm{mg} / \mathrm{kg}$ is low or deficient for a range of plants (Chapman, 1966). High levels of calcium in the substrate from application of gypsum may affect availability of magnesium and potassium. Residue analysis also shows manganese deficiency, $(<1 \mathrm{mg} / \mathrm{kg}$, Munshower, 1994). Plant available manganese is limited in bauxite residue (Gherardi and Rengel, 2003).

High pH, ESP and potentially high levels of soluble aluminium inhibit plant growth and establishment on bauxite residue. In the current study successful plant growth for the three species was achieved for the first years growth, indicating that amendment of the residue had overcome these conditions. Also, limitations in nutrients in bauxite residue are seen as a critical factor in achieving long-term growth on the residue. 
Deficiencies in nutrients such as manganese and phosphorous have been highlighted (Barrow, 1982; Gheradi and Rengel, 2003). Elemental content for the three herbage species is shown in Table 3.

Table 2 Chemical characteristics of amended bauxite residue at time of harvest, one year after sowing

\begin{tabular}{|l|l|l|l|}
\hline & Range & & Range \\
\hline Soluble & & Extractable & \\
\hline $\mathrm{Al}(\mathrm{mg} / \mathrm{kg})$ & $0.5-1.16$ & $\mathrm{Fe}(\mathrm{mg} / \mathrm{kg})$ & $3.6-6.1$ \\
\hline $\mathrm{Fe}(\mathrm{mg} / \mathrm{kg})$ & $2.5-4.3$ & $\mathrm{Mn}(\mathrm{mg} / \mathrm{kg})$ & $0.5-0.8$ \\
\hline $\mathrm{Zn}(\mathrm{mg} / \mathrm{kg})$ & $0.22-0.32$ & $\mathrm{Na}(\mathrm{mg} / \mathrm{kg})$ & $316-428$ \\
\hline $\mathrm{Na}(\mathrm{mg} / \mathrm{kg})$ & $151-239$ & $\mathrm{Ca}(\mathrm{mg} / \mathrm{kg})$ & $4687-6696$ \\
\hline $\mathrm{Ca}(\mathrm{mg} / \mathrm{kg})$ & $1161-2069$ & $\mathrm{Mg}(\mathrm{mg} / \mathrm{kg})$ & $18.4-28.6$ \\
\hline $\mathrm{Mg}(\mathrm{mg} / \mathrm{kg})$ & $4.5-5.6$ & $\mathrm{~K}(\mathrm{mg} / \mathrm{kg})$ & $20-33$ \\
\hline $\mathrm{K}(\mathrm{mg} / \mathrm{kg})$ & $8.4-8.5$ & & \\
\hline
\end{tabular}

Figure 1 shows grassland species growing on the amended residue one year after sowing. Excessive uptake of aluminium and sodium and nutrient deficiencies are of major concern with establishing vegetation on bauxite residue. Al toxicity will vary between plant species and varieties (Williamson et al., 1982). In the current study, values are significantly lower than the $474 \mathrm{mg} / \mathrm{kg}$ reported for unpolluted pasture (McGrath et al., 2001).

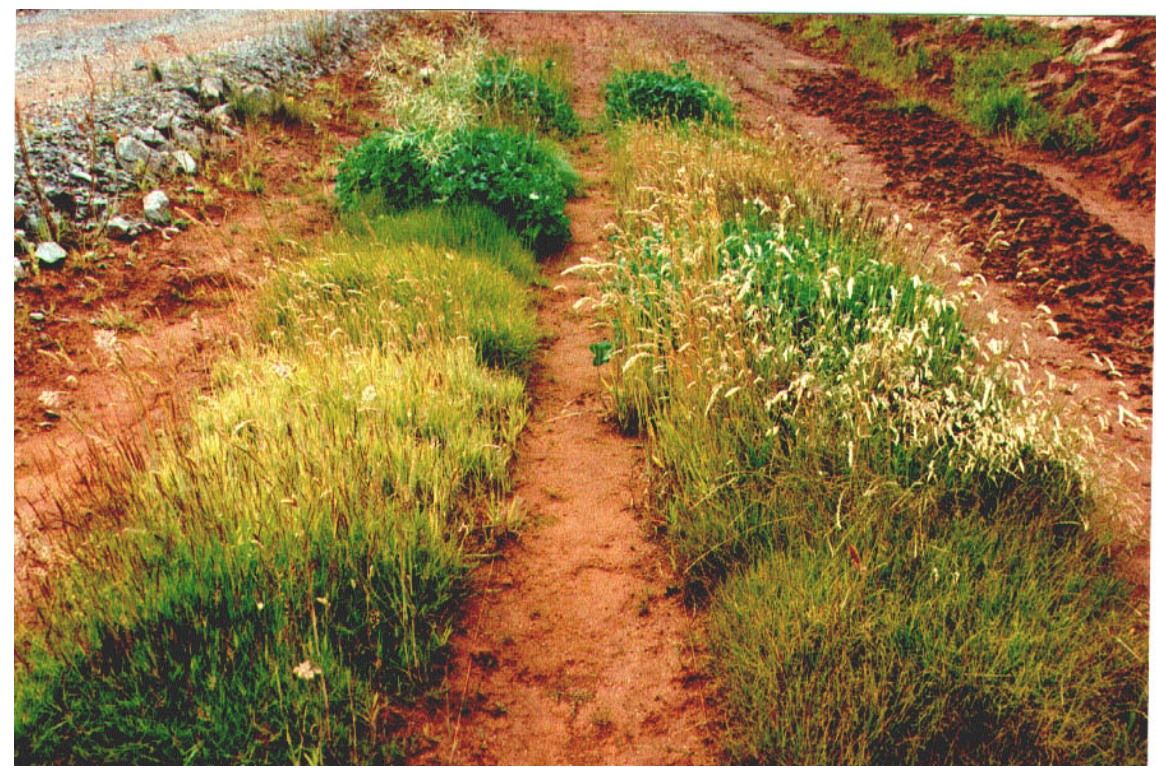

\section{Figure 1 Vegetation growing on amended bauxite residue - one year after sowing}

Plants growing in high $\mathrm{Na}$ content substrates can have impaired uptake and a subsequent low $\mathrm{Ca}$ concentration (Gupta and Abrol, 1990). In the current study, this was not the case for Trifolium. In addition, sodium content for Lolium perenne was much lower than the $0.7-1.5 \%$ range considered high for L. perenne (Reuter and Robinson, 1997). Higher levels recorded in H. lanatus may reflect an ability to accumulate higher levels of sodium. Calcium deficiency is unlikely as levels exceed the $0.25-0.3 \%$ range deemed adequate for L. perenne (Reuter and Robinson, 1997). Sodium content of the residue does not appear to have a significant impact on calcium nutrition. 


\section{Table $3 \quad$ Elemental content of plant species one year after sowing}

\begin{tabular}{|l|l|l|l|}
\hline & T. pratense & H. lanatus & L. perenne \\
\hline $\mathrm{Al}$ & 47 & 158 & 175 \\
$(\mathrm{mg} / \mathrm{kg})$ & $(4.5)$ & $(22)$ & $(61)$ \\
\hline $\mathrm{Mn}$ & 18.3 & 43.4 & 41.9 \\
$\mathrm{mg} / \mathrm{kg})$ & $(0.6)$ & $(4.7)$ & $(2.5)$ \\
\hline $\mathrm{Na}(\%)$ & 0.5 & 0.43 & 0.24 \\
& $(0.03)$ & $(0.03)$ & $(0.05)$ \\
\hline $\mathrm{Ca}(\%)$ & 1.5 & 0.52 & 0.59 \\
& $(0.1)$ & $(0.03)$ & $(0.03)$ \\
\hline $\mathrm{Mg}(\%)$ & 0.2 & 0.14 & 0.08 \\
& $(0)$ & $(0.03)$ & $(0.02)$ \\
\hline $\mathrm{K}(\%)$ & 1.6 & 0.89 & 0.89 \\
& $(0.2)$ & $(0.1)$ & $(0.1)$ \\
\hline $\mathrm{N}(\%)$ & 3.16 & 1.7 & 1.6 \\
& $(0.06)$ & $(0.08)$ & $(0.08)$ \\
\hline $\mathrm{P}(\%)$ & 0.18 & 0.32 & 0.29 \\
& $(0.06)$ & $(0.001)$ & $(0.001)$ \\
\hline
\end{tabular}

Values in parentheses are standard error of mean $(n=8)$.

Magnesium concentrations for L. perenne and T.pratense are at the lower end of the scale cited as adequate for both species (Reuter and Robinson, 1997). Plant K-concentration can be decreased in substrates of high Na-content (Gupta and Abrol, 1990). As with magnesium, potassium levels are marginally lower than values given for adequate (Reuter and Robinson, 1997).

Nitrogen nutrition on sodic and alkaline soils can be a growth-limiting factor (Curtin and Naidu, 1998). Nitrogen levels for both grass species were lower than the average value of 3.5\% for Irish grasses (Rogers and Murphy, 2000) and below the deficiency value of 1.9\% cited by Reuter and Robinson (1997). As such, nitrogen levels determined for the two grasses can be considered marginally deficient. Wong and Ho (1994) also reported deficiency for nitrogen in plants grown in red mud, with an increase in nitrogen content when the gypsum application rate was increased from $2 \%$ to $5 \%$. Even with organic amendment and inorganic fertilizer application, nitrogen levels in the present trial were low. Conversely, nitrogen nutrition in T.pratense was not adversely affected and can be considered to be adequate (Reuter and Robinson, 1997).

Limited phosphorous availability in alkaline bauxite residue has previously been reported (Barrow, 1982) and manganese deficiency has been observed in residue grown pasture (Gherardi and Rengel, 2001). Values for the two grass species are in the adequate scale reported by Reuter and Robinson (1997). Wong and Ho (1993) reported increased P nutrition on plants grown in red mud upon addition of gypsum and attributed this to $\mathrm{pH}$ reduction in the substrate. In the current study, $\mathrm{P}$ content in T.pratense is, however, deficient.

L. perenne and H. lanatus had manganese levels close to the $50 \mathrm{mg} / \mathrm{kg}$ considered adequate for many grass species. Conversely, T. pratense Mn concentration was considerably lower than the $35+\mathrm{mg} / \mathrm{kg}$ considered adequate (Reuter and Robinson, 1997). Values obtained show potential manganese deficiency and, therefore, a potential limiting constraint in achieving long-term growth of the native species on red mud. Similar results have been reported other authors (Wong and Ho, 1993; Gherardi and Rengel, 2001). 
A follow up ecological study conducted on the trial area in summer 2005 investigated species diversity on the rehabilitated area (Figure 2). Of the five species established in 1999 all continued to be present, with two, Holcus lanatus and Trifolium pretense, dominant. In addition, a further 30 herb and grass species were recorded in the rehabilitated area. Ongoing work is establishing the elemental composition of plant and soil conditions. Data analyzed from this study area will contribute to the developing revegetation prescription for the BRDA.

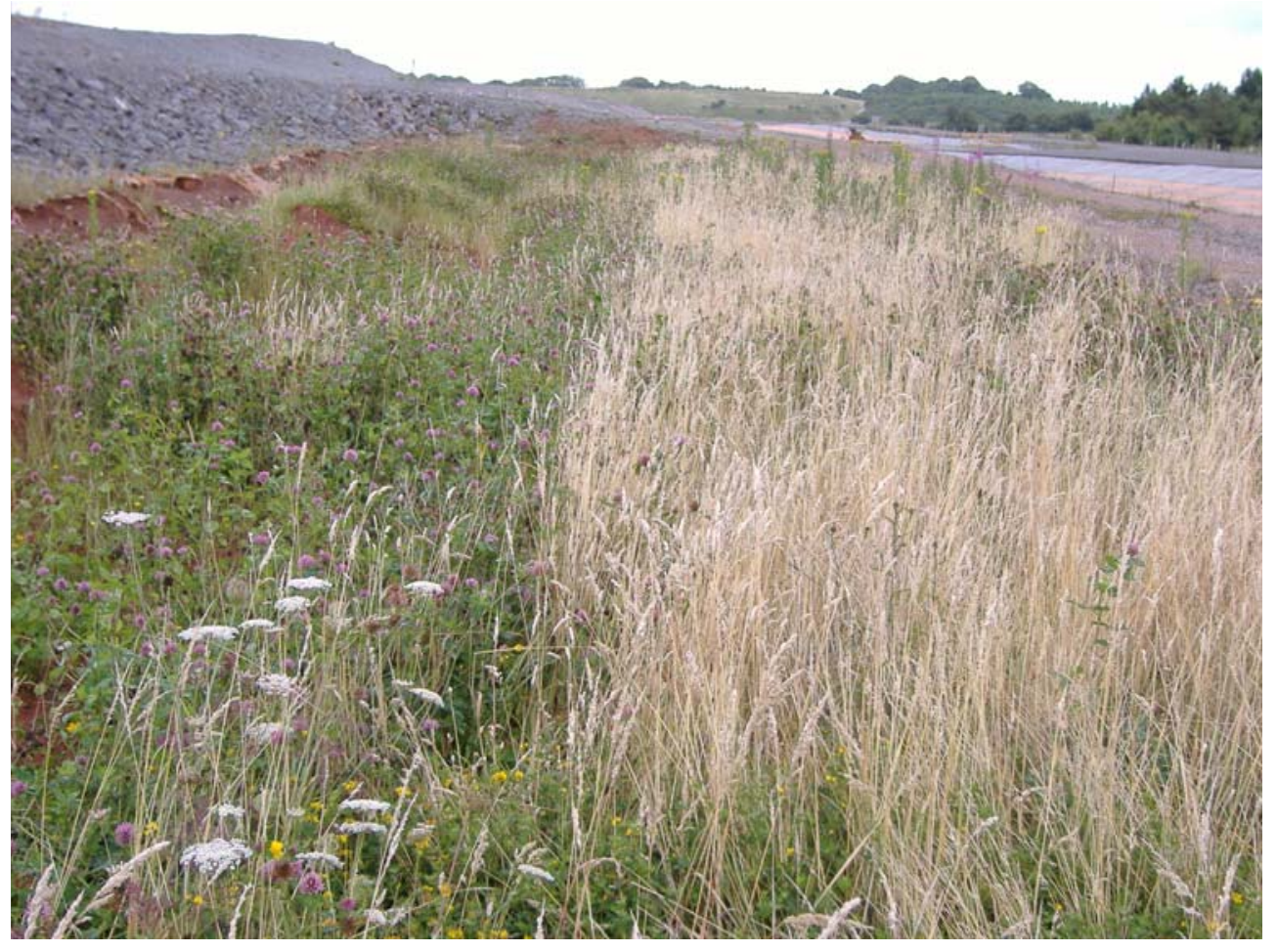

\section{Figure 2 Vegetation on amended bauxite residue -2005}

\section{CONCLUSION}

Inherent properties of the fine fraction bauxite residue presents problems in trying to achieve revegetation of the substrate. Incorporation of the sand fraction together with chemical and organic amendment overcomes the difficulties for plant establishment.

Excessive uptake of aluminium or sodium did not present a toxicological problem. It was decided that the high $\mathrm{pH}$, ESP and soluble Al characteristics of the residue previously encountered had been overcome. Calcium plant nutrition was not adversely affected by substrate conditions. However, availability and uptake of magnesium, potassium, manganese, nitrogen and phosphorous is limited. Ability to accumulate adequate amounts of these elements varies with plant species. Species diversity recorded in 2005 illustrates the potential to grow a variety of native species on amended fine fraction residue. Further analysis of substrate and plant will help determine the role of these nutrients in achieving long-term growth on bauxite residue. 


\section{ACKNOWLEDGEMENTS}

The technical and financial assistance of Aughinish Alumina Ltd is greatly appreciated. Also, the financial input of Enterprise Ireland is also acknowledged. The author is also grateful to the School of Sciences, Institute of Technology, Sligo Input from where this study was conducted.

\section{REFERENCES}

Anon (1993) Extension to bauxite residue storage area at Aughinish Island, Askeaton, Co. Limerick, environmental impact statement, Ove Arup and Partners, Limerick.

Barrow, N.J. (1982) Possibility of using caustic residue from bauxite for improving the chemical and physical properties of sandy soils, Aust. J. Agric. Res. 33, pp. 275-285.

Chapman, H.D. (1966) Diagnostic criteria for plants and soils, California, USA. University of California.

Council Directive on 15 July 1975 Waste Framework Directive (75/442), Official Journal of the European Communities No L 194

Council Directive on 12 December 1991 on Hazardous Waste Directive (91/689/EC), Official Journal of the European Communities No L 377.

Council Directive on 26 April 1999 on Landfill of Wastes (99/31), Official Journal of the European Communities No L 182.

Curtin, D. and Naidu, R. (1998) Fertility constraints to plant production, In: Sumner, M., and Naidu, R. (Eds.), Sodic Soils Distribution, Properties, Management, and Environmental Consequences, Oxford University Press, pp. 107 - 123.

Gherardi, M.J. and Rengel, Z. (2001) Deep placement of manganese fertiliser improves sustainability of lucerne growing on bauxite residue: A glasshouse study, Plant and Soil 257, pp. 85-95.

Gherardi, M.J. and Rengel, Z. (2003) Bauxite residue sand has the capacity to rapidly decrease availability of added manganese, Plant and Soil 234, pp. 143-151.

Gupta, R. and Abrol, I.P. (1990) Reclamation and management of alkali soils, Indian J. Agric. Sci. 60, pp. 1-16.

McGrath, D., Carton, O., Diamond, S., O’Sullivan, A., Murphy, W., Rogers, P., Parle, P. and Byrne, E. (2001) Soil, herbage, feed and water, in: Investigations of Animal Health Problems at Askeaton, Co. Limerick, Environmental Protection Agency, Ireland.

Meecham, J. and Bell, L. (1977) Revegetation of alumina refinery wastes. 1. Properties and amelioration of the materials, Australian Journal of Experimental Agriculture and Animal Husbandry 17, pp. 679-688.

Munshower, F. (1994) Practical Handbook of Disturbed Land Revegetation, Lewis Publishers, CRC Press, Florida.

Nguyen, Q. and Boger, D. (1987) The rheology of concentrated bauxite residue suspensions - a complete story, In: Wagh, A.S., Desai, P. (Eds.), Bauxite Tailings 'Red Mud'. The Jamaica Bauxite Institute, pp. 53-65.

Nguyen, Q. and Boger, D. (1998) Application of rheology to solving tailings disposal problems, International Journal of Mineral Processing, 54, 3-4, pp. 217-233.

Prasad, P., Chandwani, H. and Mahadevan, H. (1996) Disposal practices for bauxite tailings at the alumina refineries, Trans. Indian Inst. Net., 49, 6, pp. 817-839.

Reuter, D.J. and Robinson, J.B. (1997) Plant Analysis - An Interpretation Manual, Second Edition, CSIRO, Australia.

Rogers, P.A. and Murphy, W. (2000) Levels of dry matter, major elements and trace elements in Irish grass, silage and hay, Teagasc Publications, Wexford, Ireland.

Williamson, N. A., Johnson, M. S. and Bradshaw, A. D. (1982) Mine Wastes Reclamation, Mining Journal Books, London.

Wong, J. and Ho, G. (1993) Use of waste gypsum in the revegetation on red mud deposits: A greenhouse study, Waste Management and Research 11, pp. 249-256.

Wong, J. and Ho, G. (1994) Effectiveness of acidic industrial wastes for reclaiming fine bauxite refining residue, Soil Science 158, 2 , pp. 115-123. 